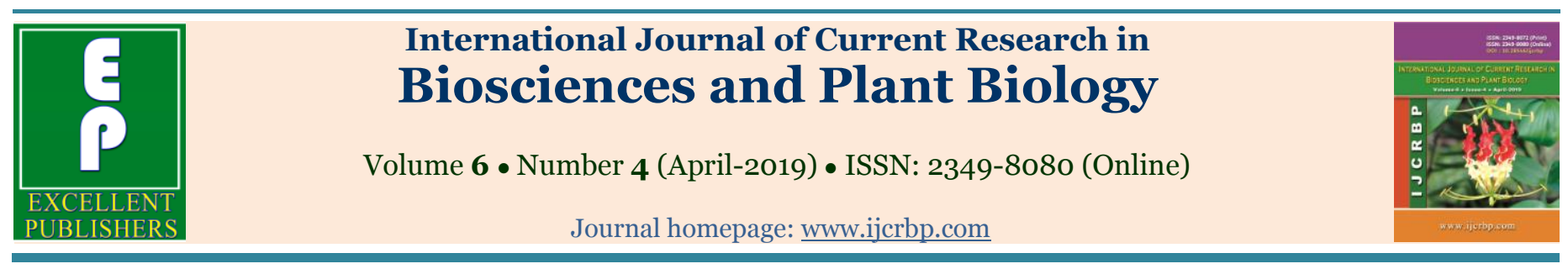

\title{
Hepato-protective and haematological assessment of Morinda lucida ethanolic leaf extract on Plasmodium berghei parasitized mice
}

\author{
R. U. Ukpanukpong ${ }^{1 *}$, D. O. Otu ${ }^{1}$, R. O. Fafioye ${ }^{2}$, A. A. Yusuff \\ and M. U. Eteng ${ }^{1}$
}

\begin{abstract}
1Department of Biochemistry, University of Calabar, Calabar, Croos River, Nigeria
2 Department of Chemical Sciences, Joseph Ayo Babalola University, Osun State, Nigeria

3Department of Biochemistry, Federal University of Technology, Akure, Ondo State, Nigeria

${ }^{*}$ Corresponding author
\end{abstract}

\begin{tabular}{|c|c|}
\hline Article Info & ABSTRACT \\
\hline $\begin{array}{l}\text { Date of Acceptance: } \\
23 \text { February } 2019\end{array}$ & \multirow{3}{*}{$\begin{array}{l}\text { Development of antimalarial drugs from medicinal plants continues to be a very } \\
\text { appealing option. Morinda lucida, commonly known as 'Oruwo' or 'Erewo' by the } \\
\text { Yoruba people of South Western Nigeria, is used in the treatment of malaria, fever, } \\
\text { amongst other ailments. Therapeutic efficacy of the ethanolic leaf extract was evaluated } \\
\text { in Plasmodium berghei infected mice. Percentage suppression of parasitaemia for the } \\
\text { ethanolic leaf extract was } 54.68,60.84,84.89 \text { and } 96 \% \text { for doses of } 100 \mathrm{mg} / \mathrm{kg} \text {, } \\
\text { 20omg/kg, and } 400 \mathrm{mg} / \mathrm{kg} \text { body weight of the extract and } 5 \mathrm{mg} / \mathrm{kg} \text { Leonart DS } \\
\text { respectively. Effective dose which depends on the inhibition of parasitaemia was also } \\
\text { observed in the curative test. The hepatoprotective activity of the ethanolic leaf extract } \\
\text { was determined through liver enzyme tests (AST, ALT, and ALP) for 100, 200, and } 400 \\
\text { mg/kg body weight of the extract. Morinda lucida ethanolic leaf extract possesses no } \\
\text { lethality in mice at } 400 m g / \mathrm{kg} \text { body weight. It is concluded that the ethanolic leaf } \\
\text { extract of Morinda lucida is potentially useful as antimalarial drug. }\end{array}$} \\
\hline Keywords & \\
\hline $\begin{array}{l}\text { Ethanolic leaf extract } \\
\text { Hemamatological indices } \\
\text { Hepatic enzyme } \\
\text { Morinda lucida } \\
\text { Phytochemicals } \\
\text { Plasmodium berghei }\end{array}$ & \\
\hline
\end{tabular}

\section{Introduction}

Malaria free world remains as much as a distant vision as ever despite more than a century effort and early optimism. Multi - drug resistance is one of the most important problems in malaria control over the years. This has led scientists and physicians to finding other solutions, one of which is investigation of medicinal plants. Sourcing of Artemisinin from Artemisia annua has further encouraged malaria phytotherapist to revisit the medicinal plants frequently used in the traditional management of the disease (Elufioye and Agbedahunsi, 2004). The world is now grapples with the possible failure of celebrated conventional drugs, due to growing resistant strains of the malaria parasite, Nigerian researchers are looking inwards for novel herbs that can beat resistant strains of the parasite (Adesida and Adesogan, 1972). Malaria is a global disease that is predominant in the tropics and caused by blood parasites, Plasmodium falciparum, Plasmodium ovale, Plasmodium malariae and Plasmodium 
vivax. In Nigeria, malaria is mostly caused by Plasmodium falciparum and Plasmodium malariae. The female anopheles mosquito transmits these parasites to humans.

According to the World Health Organization (WHO, 2014), malaria has a great morbidity and mortality than any other infectious diseases of the world. Survey shows that 90 percent of the world cases of malaria occur in this region and record over one million deaths annually. High mortality rate is recorded in children and pregnant women. The disease also has negative impact on the economy of prevalent countries (Abbiw, 2012). Medicinal plants have been used in the treatment and prevention of malaria in various parts of the world. Until now, the world has relied on plants for the best malaria drugs: chloroquine from cinchona tree, and artemisinin from Chinese salad plant, Artemissia annua. The emergence of the ineffectiveness of chloroquine in combating malaria led to additional studies, which produced artemisin. However, the malaria parasite is also developing resistance to the World Health Organization (WHO) celebrated drug, Artemisin Combination Therapies (ACT) (Burkill, 1997). This has led to intensified search for the next best malaria drug from the source of choice, plants. Unfortunately, indigenous medicinal plants in Nigeria used in combating malaria are yet to be given a look in, as the foreign plants, in spite of documented evidence of their efficacy against resistant strains of malaria. Herbal candidates for the next best malaria drug are: Cryptolepis sanguinolenta (yellow - die root or Paran pupa in Yoruba), Morinda lucida (Oruwo), Enantia chlorantha (Awopa), Alstonia boonei (Ahun), Azadirachta indica (Dongoyaro), Khaya grandifoliola (Oganwo), Annona muricata (Soursop), Mangifera indica (Mango), Bryophyllum pinnatum (Resurrection plant, formerly called Kalanchoe pinnata), Momordica charantia (Bitter melon), and Zingiber officinale (Ginger). In preparation of herbal recipes for malaria therapy, single plant (monotherapy) can be used or in combination of more than one plant. The combination of these different plants is claimed to cure several ailments and dysfunctions associated with malaria in the body. For instance, plants claimed to cure coated tongue and those that replenish blood cells during malaria attack are included in herbal recipes for malaria. They are also regarded as plants useful for malaria therapy. The treatment is observed to be traditional with deep socio-cultural expression as recognized by the WHO (Irvine, 1961).

Morinda lucida belongs to the plant family Rubiaceae. It is commonly called Brimstone tree. It is called Oruwo or Eerewo in Yoruba. Enantia chlorantha belongs to the plant family Annonaceae. It is locally known as Awopa, Oso pupa or Dokita Igbo (Yoruba). A study published in African Journal of Traditional, Complementary and Alternative Medicines concluded: Fifty species including Morinda lucida, Enantia chlorantha, Alstonia boonei, Azadirachta indica, and Khaya grandifoliola plants were found to be in use for malaria therapy at Oke - Igbo, South west, Nigeria. The parts of plants used could either be the barks, roots, leaves or whole plants. The recipes also, could be a combination of various species of plants or plant parts. This study highlights potential sources for the development of new antimalarial drugs from indigenous medicinal plants found in Oke Igbo, Nigeria. Cryptolepis sanguinolenta, which is a member of the family Apocynaceae. It is commonly called Paran pupa in the Yoruba speaking areas of Nigeria. It is a medicinal plant used by some traditional herbalist in the treatment of fever, urinary, and upper respiratory tract infections. The use of this plant as a medical therapy has increased as it has been proposed that the root and leave extracts have hypotensive, antipyretic, anti - inflammatory, anti - diarrhea, anti - diabetic, in vitro antibacterial and antimalarial effects. Cryptolepine is an indoloquinoline, high yields of which may be extracted from the roots of the West African shrub Cryptolepis sanguinolenta. The use of this plant as a traditional treatment for malaria is widespread in Ghana and is reported to be clinically effective (Hepper, 1963).

Morinda comprises about 80 species and occurs throughout the tropics. In Africa 5 species are found. The comparatively small flowering and fruiting heads on long slender peduncles are distinctive characteristics of Morinda lucida. Other Morinda species also yield yellow and red dyes, but they usually have other more important uses. Many species, including those from Africa, are important medicinal plants, widely applied against various kinds of fevers and infections. The 
powerful dye from bark and roots of Morinda citrifolia leaf is used where in Cote d Ivoire to dye traditional cotton cloth bright orange - red and the bark is also added to indigo baths to promote fermentation and to produce darker blue colours. From the root bark of Morinda longiflora G. Don the red anthraquinone colorants 1 - methylether alizarin and rubiadin have been isolated and the leaves and roots of Morinda morindoides also contain anthraquinone compounds used for red coloring.

\section{Materials and methods}

\section{Chemicals}

Chloroform, ethanol and methanol, and other chemicals were obtained from Film Lab Nigeria Limited and Lixok- chemicals, Akure respectively. Alanine Transaminase (ALT), Aspartate transaminase (AST), Serum albumen were obtained from Randox Laboratories Limited, UK. All other chemicals used were of analytical grade, also deionized and distilled water was used throughout.

\section{Experimental animals}

Adult fifty four (54) male mice weighing between $17.95-26.57 \mathrm{~g}$ were purchased from a disease free stock of the department of Biochemistry, University of Ibadan, Nigeria and used for the study. The mice were randomly assigned on the basis of their weight into six study groups of nine (9) mice each. Normal feeds and tap water were given to the animals ad-libitum and food and water intake was noted. They were kept in plastic cages of nine mice per cage placed in a wellventilated animal room of Joseph Ayo Babalola University at normal temperature of $30-35^{\circ} \mathrm{C}$. The cages were cleaned daily and the mice were treated according to the international guidelines for the care and use of laboratory animals. The animals were allowed for two weeks of acclimatization and their weights measured before treatment commenced.

\section{Plant materials}

Fresh leaves of Morinda lucida were obtained from its natural vegetation in Ikeji Arakeji forest Osun State, Nigeria. The plant samples were taking to the Department of Botany, Obafemi Awolowo University for identification and authentication.

\section{Preparation of plant extract}

Morinda lucida leaves were sorted out washed to remove debris and dust particles and air dried under shade for four (4) weeks. The dried materials were homogenized using mechanical grinder and weighed in a weighing balance. The powder form was kept in air tight container and stored at $40^{\circ} \mathrm{C}$ until when needed for further analysis.

\section{Extraction procedures}

Ethanolic Extraction: 10og of the powdered extract was soaked in $250 \mathrm{ml}$ at room temperature for 72 hours after which the mixture was filtered. The filtrate was placed in centrifuge at $3000 \mathrm{REV}$ for 30 minutes. The centrifuged sample formed two (2) layers; the upper layer was then poured inside another beaker. It was boiled at a very high temperature using water bath. During the boiling process, it was observed that the sample formed a crystal structure in a foaming form. The resulting filtrate was air dried at room temperature into polythene container in dishes. The residue obtained was weighed and kept in air -tight container at $4^{\circ} \mathrm{C}$. Percentage yield was determined from the weight of the dried sample.

\section{Induction of malaria}

Malarial was induced by single intraperitoneal dose of $0.2 \mathrm{ml} / \mathrm{kg}$ of Plasmodium berghei into one mouse for three days. After three days, the \% parasitemia level of the mouse was calculated. Parasitized erythrocytes (0.2 ml blood) were obtained from the donor-infected. Mouse by sacrificing it in Lithium Heparin-coated sample tube and made up to $10 \mathrm{ml}$ with normal saline. Animals were inoculated intraperitoneally with infected blood suspension $(0.2 \mathrm{ml})$ containing about $1 \times 10^{2}$ parasitized erythrocytes. A total of sixteen mice were inoculated, as mentioned above. Animals were observed within their groups after which their \% parasitemia of the red blood cells were calculated and those mice with \% parasitemia level more than $19.5 \%$ were isolated, classified parasitized and used for experimentation. 


\section{Percentage parasitemia of red blood cell}

This is process by which the level of the parasite (Plasmodium berghei) in the body of inoculated animals is determined. The method adopted was, by collections of the blood sample of the animals at those hours earlier mentioned (i. e). $12 \mathrm{hrs}, 24 \mathrm{hrs}$, $36 \mathrm{hrs}$, and $72 \mathrm{hrs}$ ) and made the smear of thin film on the slide. The Slides were left on the bench for few minutes to air dry. After drying, the slides were fixed using methanol and then followed by staining with Giemzar's stain. The stain was allowed to stay on the slides for about five minutes and then washed away with water. The slides were then observed under microscope using $X 100$ (oil immersion) for infected and uninfected RBC. The $\%$ parasitemia were calculated as follows.

$$
\% \text { Parasitemia of RBC }=\frac{\text { Number of infected RBC }}{\text { Total Number of RBC }} \times 100
$$

Total Number of RBC $=$ Number of infected RBC + Number of uninfected RBC.

\section{Experimental design}

The grouping and treatment given to the mice in each group is as follows:

Group A: Designated as NPC consisted of non parasitized control mice administered $1 \mathrm{ml}$ of distilled water.

Group B: Designated as PNC consisted of parasitized non control mice administered with nothing.

Group C: Designated as PO consisted of parasitized mice administered $0.5 \mathrm{ml}$ of orthodox drug (Leonart DS).

Group D: Designated as PML1 consisted of parasitized mice administered $100 \mathrm{mg}$ of leaf extract.

Group E: Designated as PML2 consisted of parasitized mice administered $200 \mathrm{mg}$ of leaf extract.

Group F: Designated as PML3 consisted of parasitized mice administered $400 \mathrm{mg}$ of leaf extract.

\section{Statistical analysis}

The data obtained were expressed as Mean \pm S.E.M (Standard Error of Mean). All results were mean of 9 determinant and statistical analysis was carried out using student's “t”-test. The values were considered at probability level of $P<0.05$.

\section{Results and discussion}

The results of the phytochemical screening carried out on the ethanolic leaf extract of Morinda lucida showed the presence of alkaloids, flavonoids, saponin, tannin, anthraquinones, phenolic compounds, and oxalates as shown in Table 1. This result of the study is in agreement with the report of (Adeneye and Agbaje, 2008). The presence of flavonoids and other bioactive constituents is believed to have contributed to the observed antiplasmodial activity of Morinda lucida leaf extracts. The result of the study showed significant decrease in the percentage parasitemia in the extract treated groups $(100 \mathrm{mg} / \mathrm{kg}, 200 \mathrm{mg} / \mathrm{kg}$, and $400 \mathrm{mg} / \mathrm{kg}$ ) when compared with the control and this is in line with (Obih et al., 1985) who observed that the bark of Morinda lucida extract has an inhibitory effect on Plasmodium berghei infected mice.

Table 1. Phytochemical screening of Morinda lucida extract.

\begin{tabular}{lll}
\hline S/N & $\begin{array}{l}\text { Phytochemical } \\
\text { components }\end{array}$ & $\begin{array}{l}\text { Morinda lucida } \\
\text { extract }\end{array}$ \\
\hline 1. & Alkaloid & + \\
2. & Flavonoids & + \\
3. & Saponin & + \\
4. & Tannin & + \\
5. & Anthraquinones & + \\
6. & Phenolic compounds & + \\
7. & Oxalates & - \\
\hline + Present; - Absent.
\end{tabular}

The results of the present study are shown in Figs. 1 -7 . There was no significant difference in weight for group $\mathrm{D}, \mathrm{E}, \mathrm{F}$, after treatment $(\mathrm{P}<0.05)$. Only group $\mathrm{C}$ showed significant decrease in body weight compared to non parasitized mice (Fig. 1). The three-day curative test carried out on ethanolic leaf extract, showed appreciable suppressive effect, as the mean parasitaemia count for the three groups treated with ethanolic extract of Morinda lucida leaf reduced drastically (Fig. 2). There was significant increase $(P<0.05)$ in the pack cell volume $(\mathrm{PCV})$ in the groups $(\mathrm{D}, \mathrm{E}, \mathrm{F}$ and $\mathrm{C})$ treated with ethanolic extract of Morinda lucida and the Leonart DS when compared with the negative control (Fig. 3), this expression shows that ethanolic extract of Morinda 
lucida leaf may be hematonic in nature and the same result was observed in hemoglobin data (Fig. 4). The drop in the PCV and hemoglobin in group B is due to malaria infection and this report is in contract with (Sowemimo et al., 2013) report that Plasmodium does not only cause the rupture of parasitized red blood cells, but stimulates the activity of macrophages in the spleen, which then destroys both parasitized and unparasitized red blood cells. The average WBC and eiosinophil also corresponds to the above results (Figs. 5 and 6).
The result of the serum enzymes (Liver function test) showed significant decrease $(P<0.05)$ for the treated groups (D, E, F) and group $\mathrm{C}$ (orthodox group), compared to the group $\mathrm{B}$ which has elevated amount of ALP, AST, ALT in the blood (Fig. 7). The elevated amounts in the values of these enzymes found in the blood are most likely related to hepatocellular damage and this is in agreement with (Williams, 1963) that attendant increase in AST, ALT may be associated with liver damage.

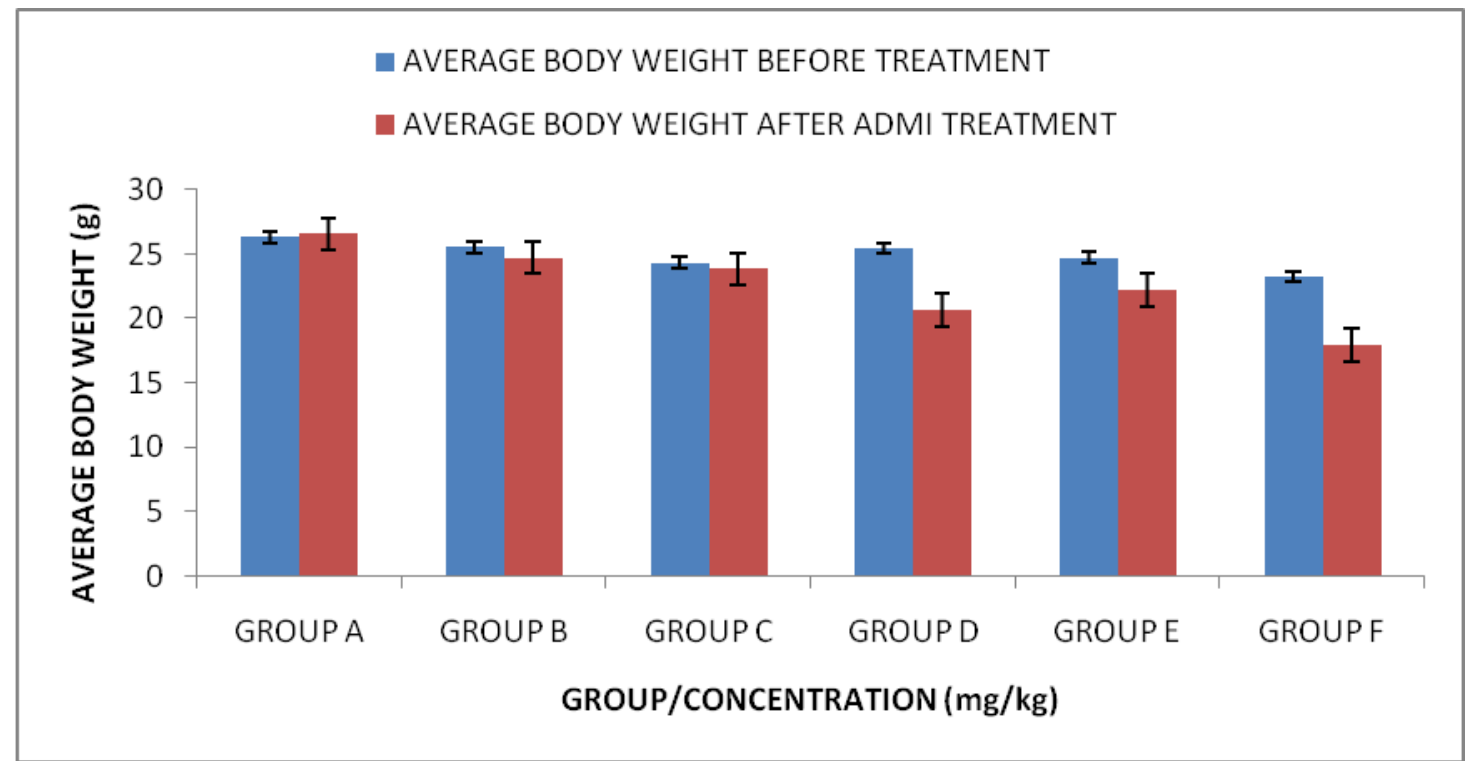

Fig. 1: The average body weight of the groups before and after 3 days of treatment. Values express in mean \pm SEM of 9 determinations.

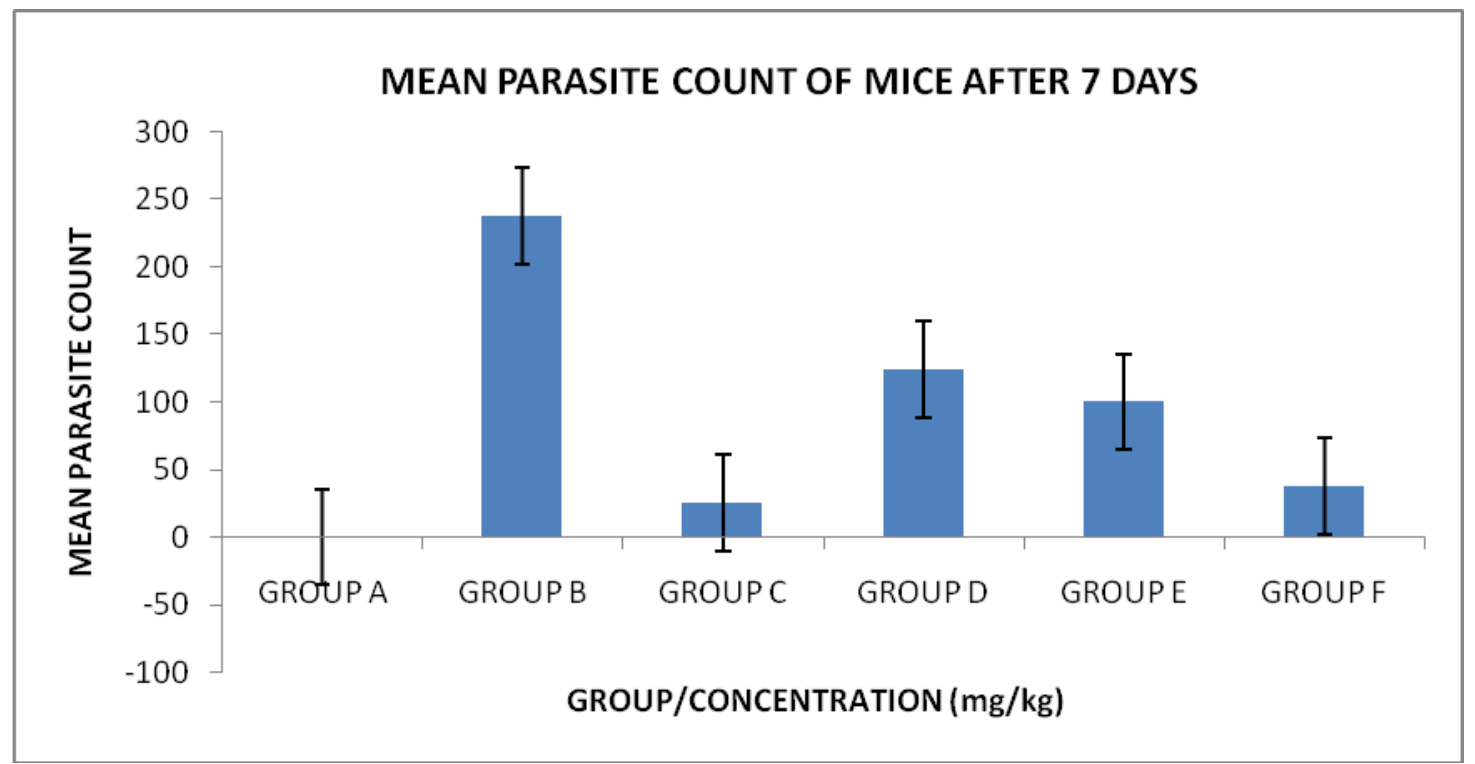

Fig. 2: The mean parasite count of the groups after 3 days of treatment ( $7^{\text {th }}$ day inoculation). Values express in mean \pm SEM of 9 determinations. 


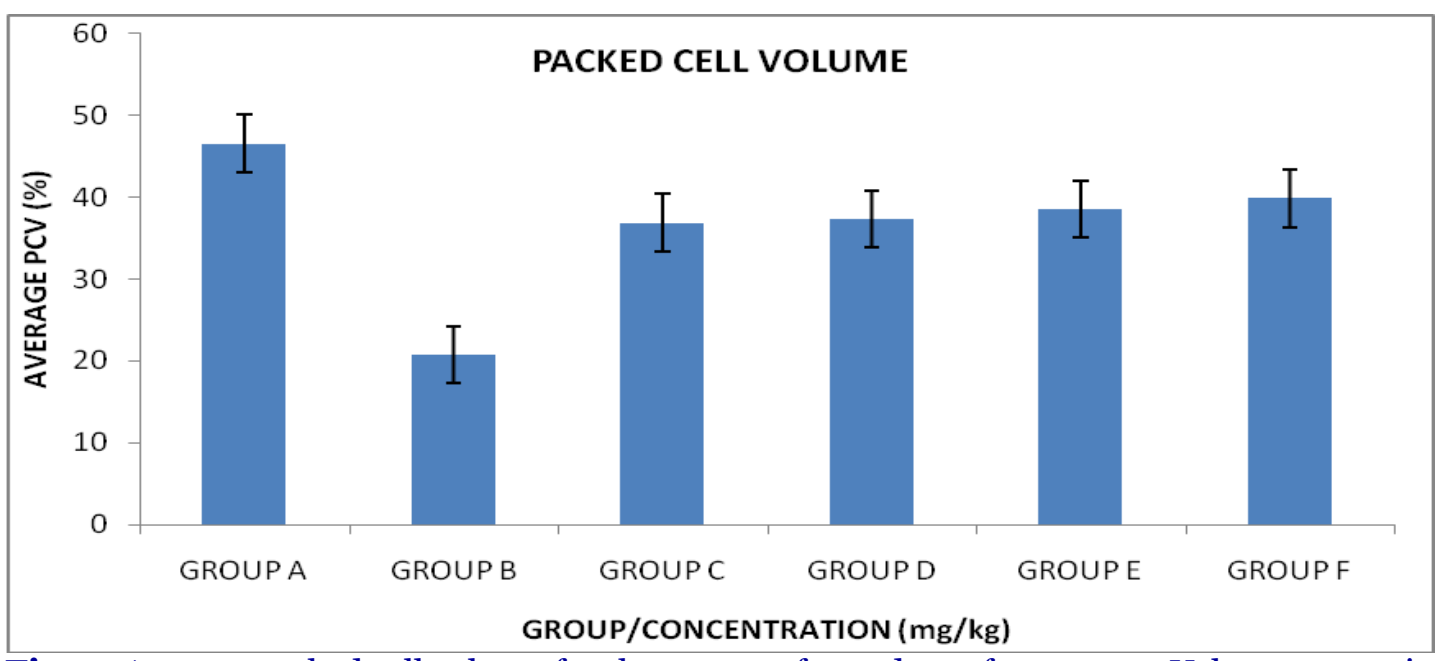

Fig. 3: Average packed cell volume for the groups after 3 days of treatment. Values express in mean \pm SEM of 9 determinations.

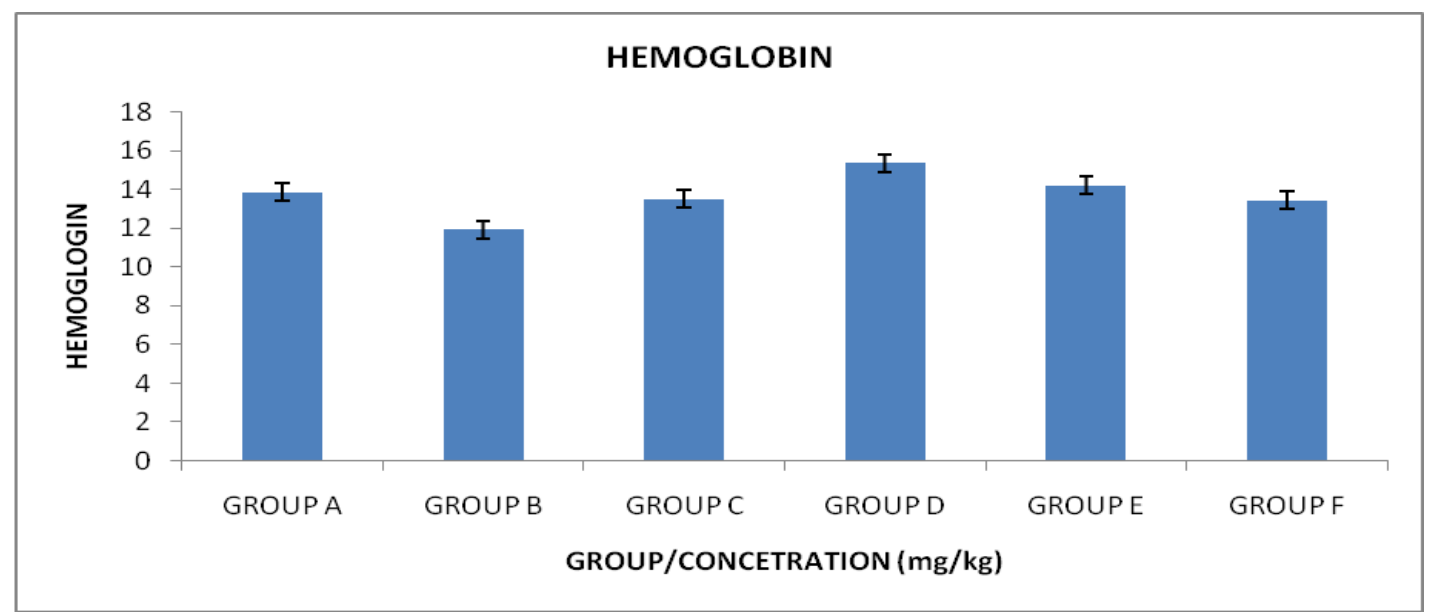

Fig. 4: Average hemoglobin count for the groups after 3 days of treatment. Values express in mean \pm SEM of 9 determinations.

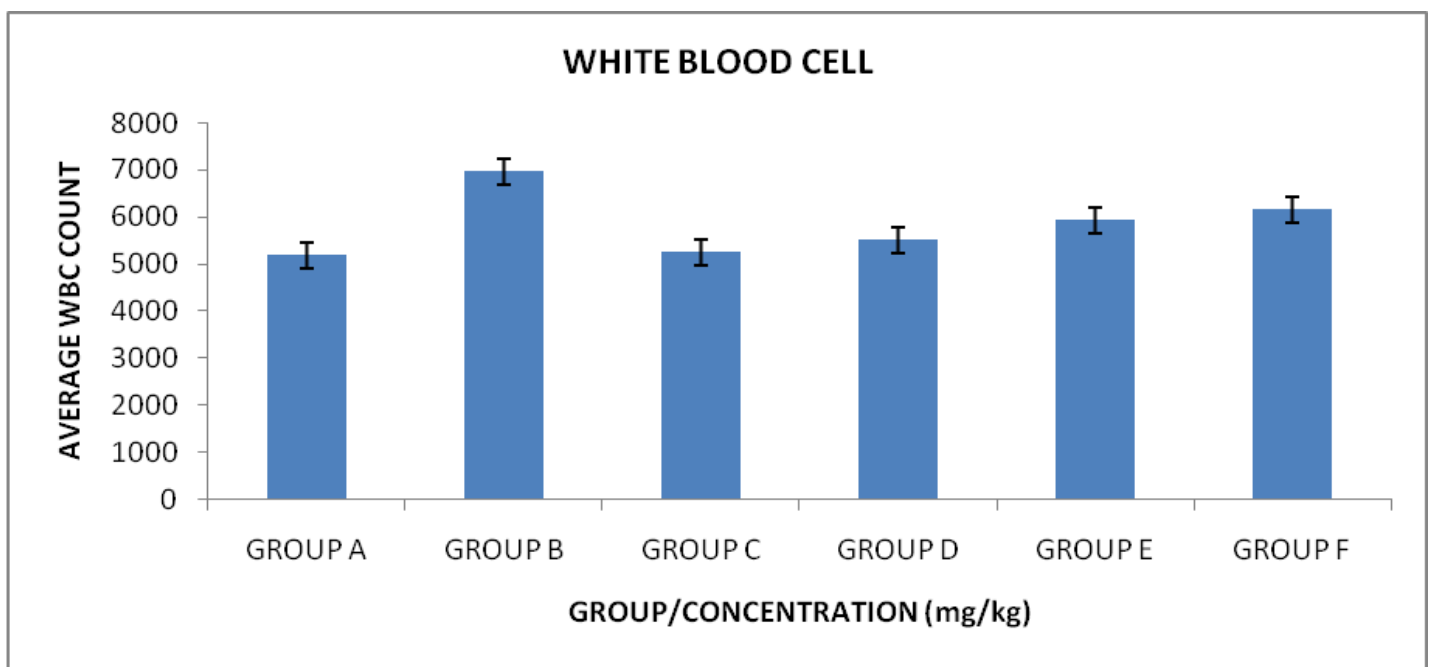

Fig. 5: Average WBC count for the groups after 3 days of treatment. Values express in mean \pm SEM of 9 determinations. 


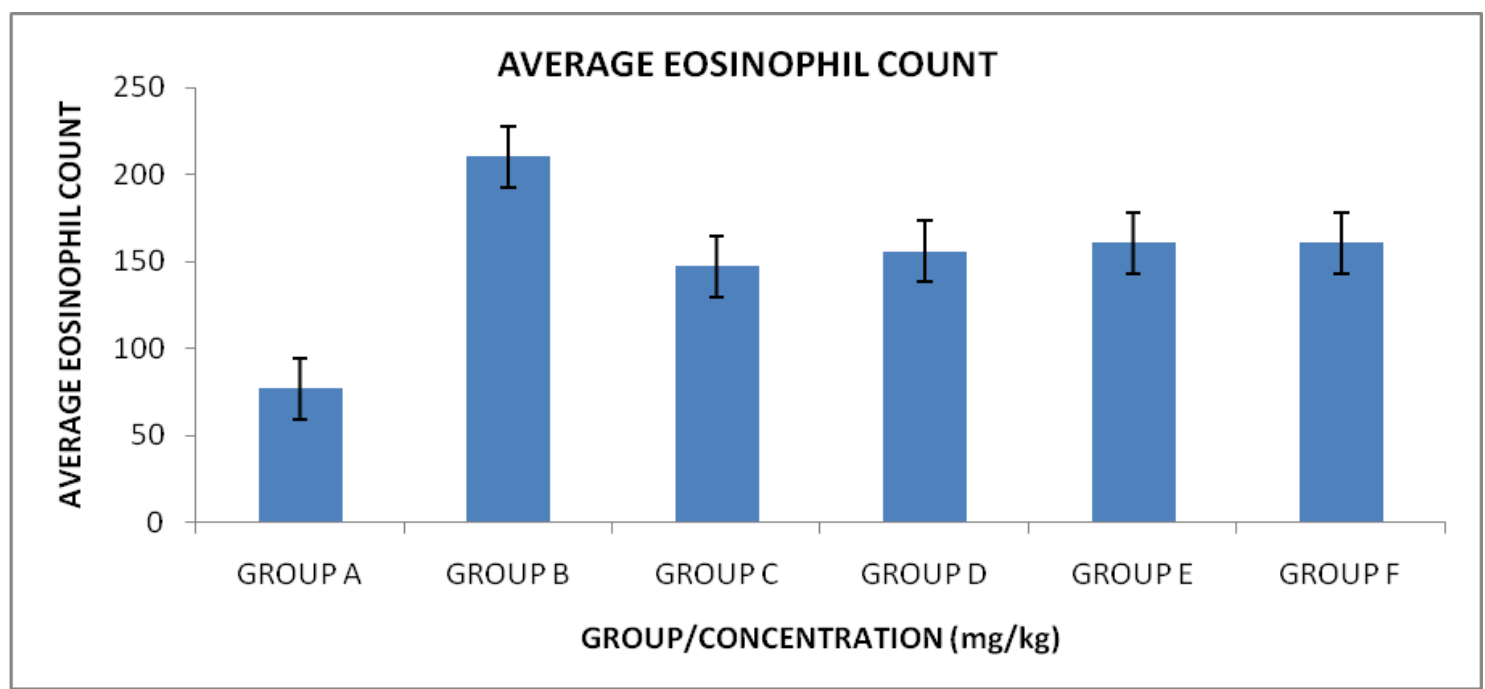

Fig. 6: Average eosinophil for the groups after 3 days of treatment. Values express in mean \pm SEM of 9 determinations.

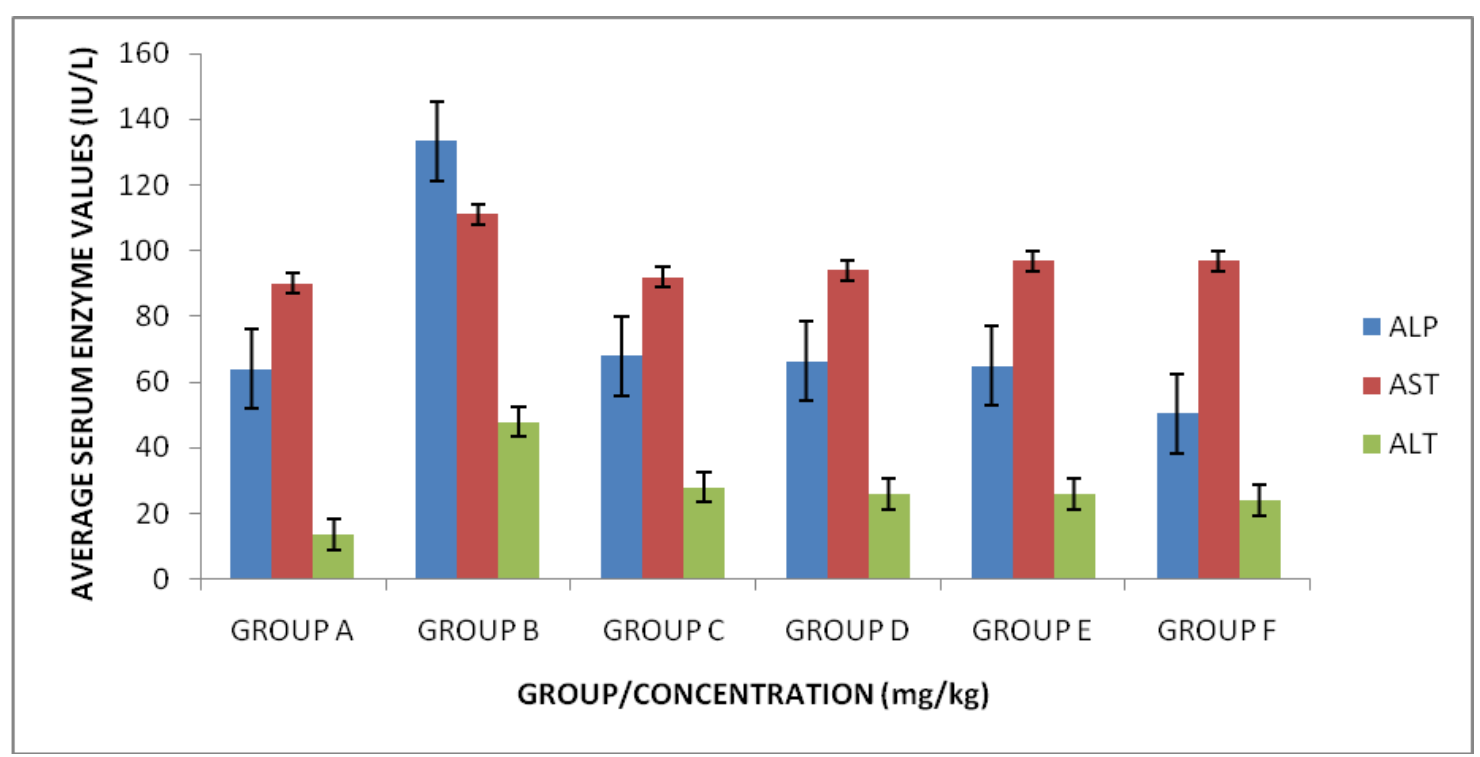

Fig. 7: Average values of serum enzymes for the groups after 3 days of treatment. Values express in mean \pm SEM of 9 determinations.

\section{Conclusion}

Morinda lucida leaf extract without doubt is a potential medicinal source considering its pharmacological activities and ethnomedical use though it has some significant toxic effect which can be reduced by administering an appropriate concentration of the extracts for a specific period, preferably short. Malaria is a common disease in Africa and the anti-malarial activity of ethanolic extract of Morinda lucida leaf may be the drug of choice when its chemotherapeutic benefits gain maximum attention by pharmaceutical firms.

\section{Conflict of interest statement}

Authors declare that they have no conflict of interest.

\section{References}

Abbiw, D.K., 2012. Useful Plants of Ghana: West African Uses of wild and Cultivated Plants. Intermediate Technology Publications, London and Royal Botanic Gardens, Kew, Richmond, United Kingdom. 337p.

Adesida, G. A., Adesogan, E. K., 1972. Oruwal, a novel dihydroanthraquinone pigment from 
Morinda lucida Benth. J. Chem. Soc. 1, 405406.

Adeneye, A. A., Agbaje, E. O., 2008. Pharmacological evaluation of oral hypoglycemic and antidiabetic effects of fresh leaves of ethanol extract of Morinda lucida Benth. in normal and alloxan induced diabetic rats. Afr. J. Biomed. Res. 11(1), 65-71.

Burkill, H. M., 1997. The useful plants of west tropical Africa. $2^{\text {nd }}$ Edn., Volume 4, families M, R Royal Botanic Gardens, Kew, United Kingdom. 969p.

Elufioye, T. O., Agbedahunsi, J. M., 2004. Antimalarial activities of Tithonia diversifolia (Asteraceae) and Crosspteryx febrifuga (Rubiaceae) on mice in vivo. $\mathrm{J}$. Ethnopharmacol. 93(11), 167-171.

Hepper, F. N., Keay, R. W. J., 1963. Rubiaceae. In: Flora of West Tropical Africa (Ed.: Hepper, F. N.). Volume 2. $2^{\text {nd }}$ Edn. Crown Agents for Oversea Governments and Administrations,
London, United Kingdom. pp.104-223. ISBN10-500-462.

Irvine, F. R., 1961. Woody Plants of Ghana, with Special Reference to their Uses. Oxford University Press, London, United Kingdom. 868p.

Obih, P.O., Makinde, J.M., Laoye, J.V., 1985. Investigation of various extracts of Morinda lucida for antimalarial actions on Plasmodium berghei in mice. Afr. J. Med. Sci. 14, 45-49.

Sowemimo, A.A., Fakoya, F.A., Awopetu, I., Omobuwajo. O.R., Adesanya, S.A., 2013. Toxicity and mutagenic activity of some selected Nigerian plants. J. Ethnopharmacol. 113(11), 427-432.

Williams, L. L., 1963. Malarial eradication in the United States. Amer. J. Pub. Health. 53(1), 1721.

World Health Organization, 2014. Malarial Fact Sheet Number 94, retrieved 28 August, 2014. pp.32-42. ISBN978-92-4156483-O.

\section{How to cite this article:}

Ukpanukpong, R.U., Otu, D.O., Fafioye, R.O., Yusuff, A. A., Eteng, M.U., 2019. Hepato-protective and haematological assessment of Morinda lucida ethanolic leaf extract on Plasmodium berghei parasitised mice. Int. J. Curr. Res. Biosci. Plant Biol. 6(4), 9-16. doi: https://doi.org/10.20546/ijcrbp.2019.604.002 